\title{
Use of raw Euphorbia tirucalli extract for inhibition of ascitic Ehrlich tumor
}

\section{Avaliação do uso do extrato bruto de Euphorbia tirucalli na inibição do tumor ascítico de ehrlich}

Orlando José dos Santos, tCbC-MA; Euler Nicolau Sauaia Filho ${ }^{2}$; Flávia Raquel Fernandes do Nascimento ${ }^{1}$; Francisco Cardoso Silva Júnior ${ }^{3}$; Eder Magalhães Silva Fialho ${ }^{1}$; Rayan Haquim Pinheiro Santos ${ }^{4}$; Rennan Abud Pinheiro Santos ${ }^{1}$; Izabel Cristina Portela BOGÉA SERRA ${ }^{1}$

\section{A}

\begin{abstract}
Objective: to evaluate the effect of the Euphorbia tirucalli hydroalcoholic extract (ETHE) on the development of Ehrlich Tumor, in its ascitic form. Methods: we intraperitoneally inoculated 15 Swiss mice with $10.44 \times 10^{7}$ cells of Ehrlich Tumor and divided them in two groups one day after: ETHE Group (eight mice), treated with a dosage of $125 \mathrm{mg} / \mathrm{kg} / \mathrm{day}$ of EHTE for five days; and Control Group (seven mice), treated only with $0.9 \%$ isotonic saline solution over the same period. The treatment was done by gavage. Ten days after inoculation, four mice from each group were sacrificed for quantification of tumor cell number, ascitic fluid volume and bone marrow cell number. The remaining animals were maintained to evaluate survival. Results: The ascitic fluid volume and the tumor cell number were decreased in the ETHE group when compared with the control group, but with no statistical significance. On the other hand, survival was higher in the ETHE group, as well as the number of bone marrow cells. Conclusion: Treatment with ETHE after inoculation of Ehrlich Tumor decreases its development and increases survival and the bone marrow cellularity, thus reducing the myelosuppression present in the Ehrlich Tumor bearing mice.
\end{abstract}

Key words: Physical Therapy Specialty. Plant Extracts. Euphorbiaceae. Carcinoma, Ehrlich Tumor. Mice.

\section{INTRODUCTION}

E uphorbia tirucalli L. [Euphorbiaceae] is known in Brazil as "aveloz", and its latex has been used as an antihelminthic, antisiphilitic and anti-tumoral agent by native people as traditional medicine $e^{1-4}$. Some biological properties of E tirucalli have been confirmed such as larvicidal, mollucide, bactericidal and anti-herpes ones ${ }^{5-9}$. These activities are likely related to the presence of phytosterols and triterpenes ${ }^{2}$.

Ehrlich Tumor is a rapidly growing carcinoma with very aggressive behavior, which induces myelosuppression in mice and strongly affects the inflammatory response. It was shown that the prostaglandin E2 (PGE2) levels, which is dramatically increased in tumour bearing mice, was also abrogated by the treatment with $E$. tirucalli extract ${ }^{10-12}$.

Based on the poplar use and on results about the effect of $E$ tirucalli on inflammatory response, our aim was to examine the in vivo antitumor activity of oral Euphorbia tirucalli, using the Ehrlich tumor in the ascitic form.

\section{METHODS}

The project was evaluated and approved by the Ethics in Research Committee at the Universidade Federal do Maranhão (UFMA), protocol n 23115 008767/200840. The study followed the guidelines for animal research as set out by the Brazilian College of Animal Experimentation (COBEA).

The sample consisted of 15 male Swiss mice (Swiss webster, Rodentia Mammalia), supplied by the UFMA vivarium. They were between 60 and 100 days old (mean 72) and weighted between $20 \mathrm{~g}$ and $25 \mathrm{~g}$ (mean 22.3g). They were kept in groups of five per standard cage for the species at the Research Laboratory of Immunophysiology, where light-dark cycle of 12 hours and humidity of $44-56 \%$, the same as a normal environment without any artificial regulation. The temperature was constant at $26 \pm 2{ }^{\circ} \mathrm{C}$. The animals were fed on standard commercial food and had free access to water.

The barks of E. tirucalli were collected and identified at the UFMA Ático Seabra Herbarium (São Luís, MA, Brazil) (specimen's voucher $N^{\circ}$ 1373). The barks were

1. Universidade Federal do Maranhão (UFMA), São Luís, MA, Brasil; 2. Hospital Universitário Presidente Dutra, UFMA, São Luís, MA, Brasil; 3. Hospital de Câncer de Barretos, Barretos, SP, Brasil; 4. Universidade Federal da Paraíba (UFPB), João Pessoa, PB, Brasil. 
mechanically triturated, added to $1 \mathrm{~L}$ of ethanol $(70 \%)$ and mixed each $8 \mathrm{~h}$ for $72 \mathrm{~h}$. After this period the hydroalcoholic extract was filtered using a cotton funnel. After this process the extract was concentrated using a rotatory evaporator and filtered again, when we obtained $190 \mathrm{ml}$ of hydroalcoholic extract. Finally, the extract was dried and the dry residue obtained was diluted in distilled water in a concentration of $15 \mathrm{mg} / \mathrm{ml}$.

To treat the mice, the E. tirucalli extract was diluted again in water and given by gavage with a daily single doses (125mg/kg body weight) during five days. The treatment was initiated 24 hours after the Ehrlich tumor implantation. The control group was treated only with isotonic saline solution $(0,2 \mathrm{ml})$.

The Ehrlich ascitic tumor, derived from a spontaneous murine mammary adenocarcinoma, was maintained in the ascitic form by passages in Swiss mice, by weekly transplantation at the UFMA Immunophysiology Laboratory. The ascitic fluid was removed by opening the abdomen and carefully collecting all the fluid with the help of a sterile $3 \mathrm{ml}$ syringe. Ascitic tumor cell counts were done in a Neubauer hemocitometer. The cells were found to be more than $99 \%$ viable by the Trypan blue dye exclusion method and amounted $5.22 \times 10^{8}$ cells $/ \mathrm{ml}$ of ascitic fluid.

A volume of $0,2 \mathrm{ml}$ of Ehrlich tumor cells was injected intraperitoneally for the development of the ascitic form. The final amount of tumor cell suspension used in each application was $10.44 \times 10^{7}$ viable cells.

After inoculation, the animals were randomly distributed into two groups: ETHE Group (EG), with eight mice, and control group (CG), with seven animals. The animals with ascitic tumor were weighted each three days.

On the day following inoculation, EG animals received daily $125 \mathrm{mg} / \mathrm{kg}$ of the hydroalcoholic extract by gavage and the CG, the same volume of $0.9 \%$ isotonic saline solution, all for five consecutive days.

On the $10^{\text {th }}$ day after inoculation, four mice from each group were killed by a lethal dose of $2 \%$ xylazine $(20 \mathrm{mg} / \mathrm{kg}, \mathrm{IM})$ and $5 \%$ ketamine hydrochloride $(30 \mathrm{mg} / \mathrm{kg}$, IM) for cell counting from the femoral bone marrow, as well as dosage of ascitic fluid volume and cellularity. The remained mice (four in EG and three in CG) were maintained to survival evaluation.

Results were expressed as the mean \pm standard deviation from four animals per group. Statistical evaluation was done by ANOVA test. The survival of mice was demonstrated using the Kaplan-Meier curve and the log-rank statistical test was applied to compare the curves. Differences were considered significant at $p<0.05$ and are represented by an asterisk. All experiments were repeated at least two times.

\section{RESULTS}

The total ascitic volume and total tumor cell number were lower in mice treated with E. tirucalli (125mg/
$\mathrm{Kg}$ ), though with no statistical significance (Figure $1 \mathrm{~A} \mathrm{e} \mathrm{B}$ ). The $E$. tirucalli treatments also significantly increased the life expectancy (Figure 1C).

There was also a significant increase in the femoral bone marrow cell number in the EG (Figure 2). EG (Figure 3).

The average weights were significantly lower in

\section{DISCUSSION}

We observed that the ascitic fluid volume and the number of Ehrlich tumor cells in the peritoneum were lower in mice treated with E. tirucalli, but this difference was not statistically significant. Despite that, this decrease could mean the inhibition of ascitic growth in EG mice. This fact, combined with the significantly lower average weights in EG, suggests tumor growth slowing in animals treated with the extract.

The exact mechanism by which E. tirucalli mediates its anti-tumor effect is unknown. However, some compounds present in E. tirucalli, such as terpenes, could explain these results13. These compounds have been mentioned as antioxidant and consequently can be involved in anti-tumor activities ${ }^{14}$. Plant derived extracts containing antioxidant principles showed cytotoxicity towards tumor cells and antitumor activity in experimental animals ${ }^{15-17}$.

The inflammatory response is, in fact, essential to modulate the development of tumors. It was

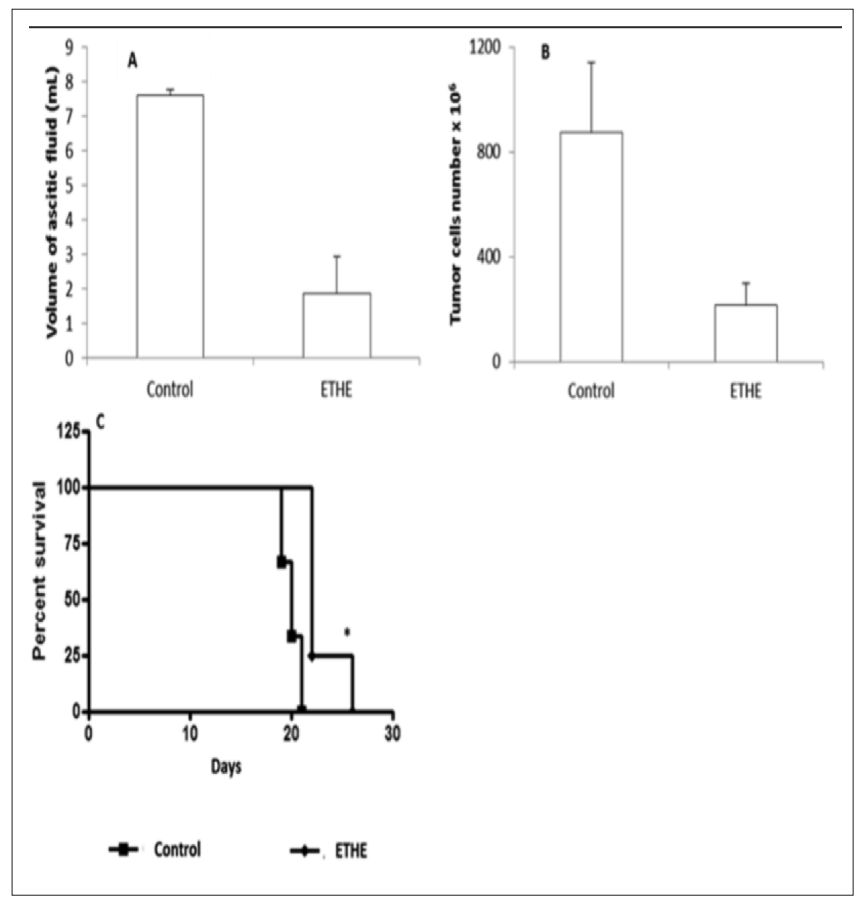

Figure 1 - Effect of E. tirucalli on ascitic Ehrlich tumor on ascitic fluid volume(A), number of tumor in ascitic fluid (B) and mice survival (C).

${ }^{*} p<0.05$ in comparison with the control group. 


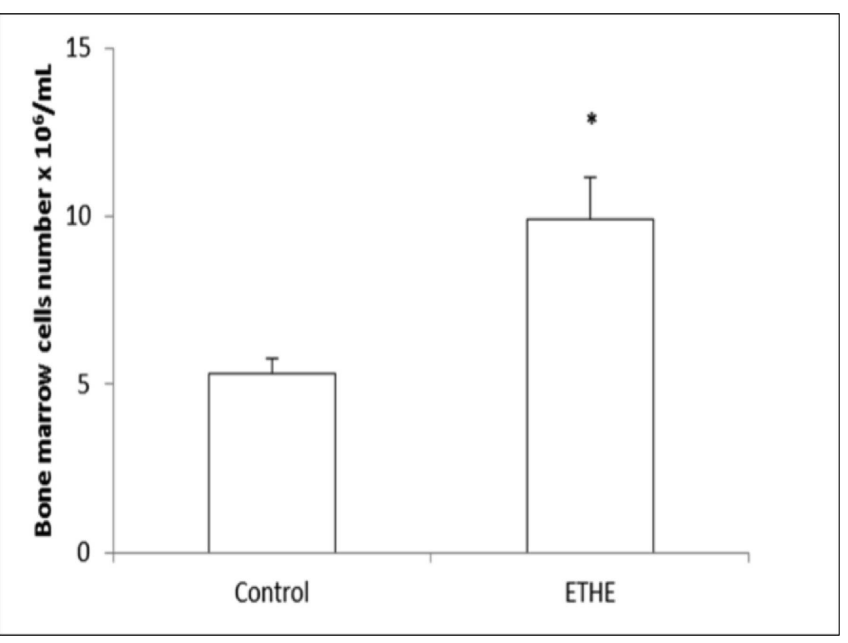

Figure 2 - Effect of E. tirucalli on femoral bone marrow cell number in Ehrlich tumor bearing mice.

${ }^{*} p<0.05$ when compared with the control group.

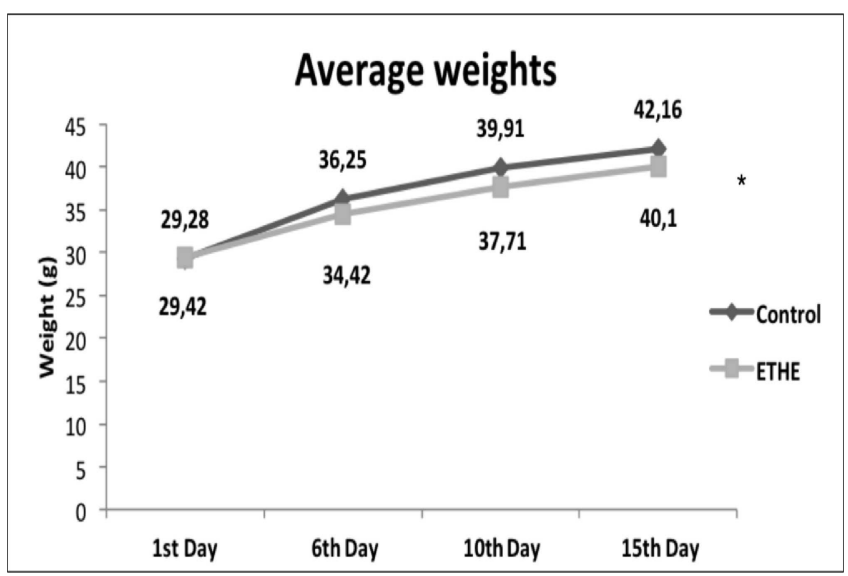

Figure 3 - Evolution of the average weight of EG and CG mice on the $1^{\text {st }}, 6^{\text {th }}, 10^{\text {th }}$ and $15^{\text {th }}$ days of trial.

${ }^{*} p<0.05$ when compared with the control group.

demonstrated that the neutrophilic inflammatory response is essential to the Ehrlich tumor's control. However, the high influx of these cells promotes tumor development ${ }^{18}$.
This effect is probably related with the angiogenesis and growth factors induced by inflammation, which are necessary to tumor development. The implantation o the Ehrlich ascitic tumor itself is sufficient to induce a local inflammatory reaction, with increased vascular permeability, which results in intense edema formation, cellular migration and a progressive ascitic fluid formation ${ }^{19}$. The ascitic fluid is essential to the tumor growth, since it constitutes the direct nutritional source for the tumor cells ${ }^{20}$.

The Ehrlich tumor growth leads to inhibition of superoxide dismutase and catalase enzymes, which are fundamental in the elimination of free radicals such as superoxide and hydrogen peroxide ${ }^{21,22}$. In Ehrlich tumorbearing mice the anti-oxidants act by a mechanism that involves modulating lipid peroxidation and augmenting the antioxidant defense system ${ }^{20}$.

We propose that the additive and synergistic antioxidant activity of phytochemicals such as terpenoids, present in E. tirucalli, are responsible for its potent antitumor activity, which can be inferred from the increased life span of tumor bearing mice and from the inhibition of ascitic growth.

As for the femoral bone marrow cellularity, there was a significant increase in the number of cells in the group treated with aveloz, a result that is consistent with what was exposed by Valadares et al. ${ }^{23}$. This author described the property of the extract of Euphorbia tirucalli to restore marrow myelopoiesis suppressed by Ehrlich tumor during its natural course, not finding, however, differences between the three doses $(125,250$ and 500 $\mathrm{mg} / \mathrm{kg}$ ). Studies in mice inoculated with Ehrlich tumor showed a rapid decrease of granulocytic and macrophage colony forming units (CFU-GM) in the bone marrow, while observing a progressive increase in cell number and CFUGM in the spleen, followed by splenomegaly ${ }^{24}$.

Regarding survival, we found a statistically significant increase in animals treated with aveloz. The same was reported by Valadares for all doses offered $(125,250$, and $500 \mathrm{mg} / \mathrm{kg} /$ day for five days), suggesting a dosedependent increase in survival (survival greater in animals treated with $500 \mathrm{mg} / \mathrm{kg}$ of the extract) ${ }^{23}$.

\section{R E S U M O}

Objetivo: avaliar o efeito do extrato hidroalcoólico de Euphorbia tirucalli (ETHE) sobre o desenvolvimento do tumor de Ehrlich em

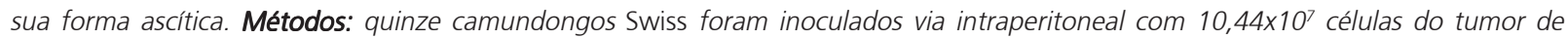
Ehrlich e um dia depois foram divididos em dois grupos: Grupo ETHE (oito camundongos), tratados com a dose de 125mg/kg/dia de ETHE por cinco dias e Grupo Controle (sete camundongos), tratado apenas com 0,9\% de solução salina isotônica em relação ao mesmo período. O tratamento foi realizado por gavagem. Dez dias após a inoculação, quatro animais de cada grupo foram sacrificados para a quantificação do número de células de tumor, do volume de fluido ascítico e do número de células da medula óssea. Os demais animais foram mantidos, para avaliar a sobrevivência. Resultados: o volume de líquido ascítico e do número de células tumorais foram menores no grupo ETHE quando comparado ao grupo controle, porém sem significância estatística. Por outro lado, a sobrevivência dos animais foi maior no grupo de ETHE, bem como, a quantidade de células de medula óssea. Conclusão: o tratamento com ETHE, após a inoculação do tumor, diminuiu o seu desenvolvimento e aumentou sobrevida, bem como, a celularidade da medula óssea, reduzindo assim, a mielossupressão presente nos animais portadores de tumor de Ehrlich.

Descritores: Fitoterapia. Extratos Vegetais. Euphorbiaceae. Carcinoma de Ehrlich. Camundongos. 


\section{REFERENCES}

1. Hecker E. Cocarcinogenic principles from seed oil of Croton tiglium and from other Euphorbiaceae. Cancer Res. 1968;28(11):233849.

2. Khan AQ, Ahmed Z, Kazml NU, Malik A. Further Triterpenes from the Stem Bark of Euphorbia tirucalli. Planta Med. 1987;53(6):577.

3. Rezende JR, Rodrigues SB, Jabor IAS, Pamphiie JA, Rocha LMSC. Efeito antimutagênico do látex de Euphorbia tirucalli no sistema metionina em Aspergillus nidulans. Acta sci biol sci. 2004;26(4):4814.

4. Silva AC, Faria DE, Borges NB, Souza IA, Peters VM, Guerra Mde O. Toxicological screening of Euphorbia tirucalli L.: developmental toxicity studies in rats. J Ethnopharmacol. 2007;110(1):154-9.

5. Tiwari $S$, Singh $P$, Singh A. Toxicity of Euphorbia tirucalli plant against freshwater target and non- target organisms. Pak J Biol Sci. 2003:6(16):1423-9.

6. Jurberg P, Cabral Neto JB, Schall VT. Molluscicide activity of the "Avelós" plant (Euphorbia tirucalli, L.) on Biomphalaria glabrata, the mollusc vector of schistosomiasis. Mem Inst Oswaldo Cruz. 1985;80(4):423-7.

7. Betancur-Galvis LA, Morales GE, Forero JE, Roldan J. Cytotoxic and antiviral activities of colombian medicinal plant extracts of the Euphorbia genus. Mem Inst Oswaldo Cruz. 2002:97(4):541-6.

8. Lirio LG, Hermano ML, Fontanilla MQ. Note antibacterial activity of medicinal plants from the Philippines. Pharm Biol. 1998;36(5):3579.

9. Fürstenberger $G$, Hecker $E$. On the active principles of the Euphorbiaceae, XII. Highly unsaturated irritant diterpene esters from Euphorbia tirucalli originating from Madagascar. J Nat Prod. 1986;49(3):386-97.

10. Segura JA, Barbero LG, Márquez J. Ehrlich ascites tumour unbalances splenic cell populations and reduces responsiveness of T cells to Staphylococcus aureus enterotoxin B stimulation. Immunol Lett. 2000;74(2):111-5.

11. Baiochi E, Bigonha JG, Heymann RE, Feder D, Cabral M, Zyngier SB. Estrógeno em tumor de Ehrlich: estudo da sobrevida e avaliação da resposta imunológica. Arq méd ABC. 1986;9(1-2):22-7.

12. Zyngier S, Bueno MAS, Krybus J, Novak A, Feder D, Cabral M, et al. Alteração da resposta inflamatória e imunológica em animais portadores de tumor experimental. Arq méd ABC. 1991;14(1):247.

13. Kiuchi F, Itano Y, Uchiyama N, Honda G, Tsubouchi A, NakajimaShimada J, et al. Monoterpene hydroperoxides with trypanocidal activity from Chenopodium ambrosioides. J Nat Prod. 2002:65(4):509-12.
14. Liu RH. Potential synergy of phytochemicals in cancer prevention: mechanism of action. J Nutr. 2004;134(12 Suppl):3479S-85S

15. Li JJ, Oberley LW. Overexpression of manganese-containing superoxide dismutase confers resistance to the cytotoxicity of tumor necrosis factor alpha and/or hyperthermia. Cancer Res. 1997; 57(10):1991-8.

16. Ruby AJ, Kuttan G, Babu KD, Rajasekharan KN, Kuttan R. Antitumour and antioxidant activity of natural curcuminoids. Cancer Lett. 1995:94(1):79-83.

17. Nascimento FR, Cruz GV, Pereira PV, Maciel MC, Silva LA, Azevedo AP, et al. Ascitic and solid Ehrlich tumor inhibition by Chenopodium ambrosioides $\mathrm{L}$. treatment. Life Sci. 2006;78(22):2650-3.

18. Bergami-Santos PC, Mariano M, Barbuto JA. Dual role of polymorphonuclear neutrophils on the growth of Ehrlich ascites tumor (EAT) in mice. Life Sci. 2004;75(2):245-55.

19. Fecchio $D$, Sirois $P$, Russo $M$, Jancar $S$. Studies on inflammatory response induced by Ehrlich tumor in mice peritoneal cavity. Inflammation. 1990;14(1):125-32.

20. Gupta M, Mazumder UK, Kumar RS, Kumar TS. Antitumor activity and antioxidant role of Bauhinia racemosa against Ehrlich ascites carcinoma in Swiss albino mice [corrected]. Acta Pharmacol Sin. 2004;25(8):1070-6

21. Sun XS, Xu Y, Xia YJ. Determination of E-rosette-forming lymphocytes in aged subjects with Taichiquan exercise. Int J Sports Med. 1989;10(3):217-9.

22. Rushmore TH, Pickett CB. Glutathione S-transferases, structure, regulation, and therapeutic implications. J Biol Chem. 1993;268(16):11475-8.

23. Valadares MC, Carrucha SG, Accorsi W, Queiroz ML. Euphorbia tirucalli L. modulates myelopoiesis and enhances the resistance of tumour-bearing mice. Int Immunopharmacol. 2006;6(2):294-9.

24. Queiroz ML, Valadares MC, Bincoletto C, Dieamant GC. Ehrlich ascites tumor as a tool in the development of compounds with immunomodulatory properties. Immunopharmacol Immunotoxicol. 2004;26(4):511-25.

Received in: 08/04/2015

Accepted for publication: 26/11/2015

Conflict of interest: none.

Source of funding: none.

\section{Mailing address:}

Orlando José dos Santos

E-mail: orlanddojs@hotmail.com 